\title{
Energy Rich Composite Millet and Soybean based Malted Weaning Mix: A Complementary Food in Tribal Areas of Adilabad District, India
}

\author{
A. Poshadri, Y. Praveen Kumar*, G. Shiva Charan, M. Raghuveer, \\ M. Sunil Kumar and A. Rama Devi
}

\begin{abstract}
Krishi Vigyan Kendra, Professor Jayashankar Telangana State Agricultural University, Adilabad-504002, India
\end{abstract}

*Corresponding author

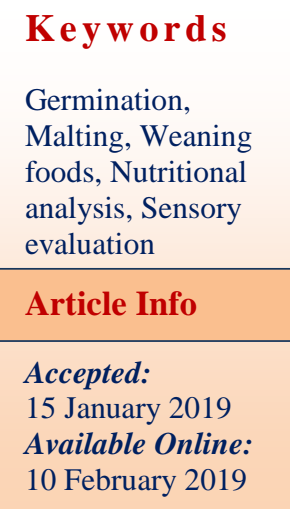

\section{Introduction}

Adilabad is one of the districts inhabited by highest number of tribal people in India with more than $75 \%$ rural population and among them $35 \%$ of people are tribes. Majority of the farmers are marginal and small accounting to $67.8 \%$ of total land holdings in the district. In total gross cropped area of the district, pulses, soybean and cotton occupy $18 \%, 12 \%$ and
Prevalence of malnutrition among infants, young children and nursing mothers is common in tribal areas of Adilabad district of India, although district endowed with higher production of Soybean, Sorghum, wheat and millets that could be harnessed through processing to produce energy dense nutritious foods. Germination and milling of germinated grains into malt is a simple process that is widely used for making complementary nutritious weaning foods from locally grown cereals and pulses. The nutrient contents of energy rich complementary weaning foods $(17.1 \pm 0.1 \%, 18.7 \pm 0.3$ and $18.5 \pm 0.6$ protein, and 367, 373 and $371, \mathrm{kcal} / 100 \mathrm{~g}$ for Sample-A, Sample-B and Sample$\mathrm{C}$, respectively fall in the category of protein-rich supplementary foods for children and mothers. The mean scores of sensory evaluation showed that all the energy rich complementary weaning food samples prepared from locally grown foods were within the acceptable range, while the energy rich complementary weaning food sample-B (Sorghum: Wheat: Ragi: Soybean: Green Gram in the ratio of 35:20:10:20:15) significantly had nutritionally superior quality with the acceptable sensory attributes. Further study also shows that the tribal families can prepare energy rich weaning mixes from their agriculture produce by simple malting and milling process. 
Telangana state is producing 2, 52,017 MT of soybean from an area of 0.24 million hectares (Directorate of Economics and Statistics2017) and Adilabad district shares $39.6 \%$ area with the production $38.2 \%$ of total states' soybean production. Adilabad district also produces 19215 MT sorghum and millets per year from an area of 20030 ha and sharing $23.5 \%$ of state production.

Millets are nutritionally superior to major cereal grains. The additional health benefits of the millets like gluten-free proteins, high fibre content, low glycaemic index and richness in bioactive compounds made them a suitable health food (Kannan et al., 2013). The average carbohydrates content of millets and sorghum varies from 56.88 to $72.97 \mathrm{~g} / 100 \mathrm{~g}$, protein content of 7.5 to $12.5 \%$ and lipid content ranges from 1.3 to $6 \mathrm{~g} / 100 \mathrm{~g}$ and richest source of fibres, i.e. crude fibre as well as dietary fibre and also is rich in vitamins, minerals (Longvah et al., 2017).

Soybeans are rich in protein and fat content, which accounts for about $60 \%$ of dry soybeans by weight (Kuan-I Chen et al., 2012). The high quality protein content in soybean makes soybean is an important and cheap source of complete protein (Henkel 2000) to control protein energy malnutrition in tribal areas of the district. A whole soybean has a Protein Digestibility Corrected Amino Acid Score (PDCAAS) of 96, soybean milk 91, and eggs 97 Kuan-I Chen et al., 2012).

Protein Calorie Malnutrition (PCM)' is a major concern in Adilabad district especially in infants, young children and nursing mothers in tribal areas. About $35.8 \%$ children below 5 years under weight (weight for age), $38.3 \%$ children below 5 years under stunted (Height for age) and $67.8 \%$ children less than 5 years are suffering with anaemic problems (NFHS-4 data, 2015-16). Building awareness on preparation of composite soy and millet based foods and consumption can support the complementary diet, well-being, and livelihoods of tribal communities and farmers in Adilabad district of India, where malnutrition and anemia are common among infants, young children and nursing mothers.

However, the soybean, millets and sorghum consumption in tribal areas is in wane because of lack of awareness on nutritional importance, cultural changes towards polished rice consumption and gaps in processing and poor linkages to markets. Apart from their nutritional benefits, the health benefits of soybean, sorghum and millets such as control of diabetes, anaemia, cardiovascular, and celiac diseases are not properly exploited fully. Therefore to increase the consumption of locally grown foods such as soybean, sorghum and millets by tribal families an attempt was made to develop energy dense foods from composite blends of soybean and millets and sorghum. In recent years due to climate variations, mono cropping, high intensity of pests and diseases, non judicious use of chemicals are affecting the yields and increasing the cost of cultivation in the district and it leads paradigm shift in cultivation of sorghum and millets than cotton.

In view of the above advantages, this study is undertaken to design energy dense and highly nutritious complementary food from soybean, sorghum and millets using malting technology and conducted a supplementation study through ANGANWADI centres in Tribal areas.

\section{Materials and Methods}

Freshly harvested Sorghum, Pearl millet, Wheat, Green gram and Soybean were obtained from Krishi Vigyan Kendra, Adilabad. Sugar and milk powder were collected from local markets. All other reagents were of analytical grade. Experiment 
was carried out at Krishi Vigyan Kendra, Adilabad and ANGANWADI centres in Tribal areas.

\section{Sample preparation}

The Sorghum, Pearl millet, Wheat, Green gram and Soybean were sorted in order to remove foreign materials, mouldy or broken and damaged grains (which may affect the taste and keeping quality of the product) and washed under running water.

\section{Production of composite malted flour}

The cleaned Sorghum, Pearl millet, Wheat, Green gram and Soybeans were malted separately following the method described by Anigo et al., 2010 and Adelekan and Oyewole (2010) with slight modification. The Sorghum, Pearl millet, Wheat, Green gram and soybeans were soaked in potable water at ambient temperature for $12 \mathrm{hr}$. At the end of the soaking period, the moisture content of the grains had increased to $40-45 \%$. The hydrated grains were spread separately on a moist cotton cloth (which had been previously sterilized by boiling in water bath for 30 mins) placed on a tray and kept in a cabinet. The grains were allowed to germinate for 1-3 days depending on the nature of the grains. The grains were watered twice daily and nongerminated ones removed. The sprouted grains were dried in a cabinet drier $\left(60^{\circ} \mathrm{C}\right)$ until a moisture content of $12-15 \%$ was reached. Then the sprouted grains were roasted in separately on roasting pan and the malted grain flours were blended to formulate complementary energy rich foods (Table 1). Then the blend was milled in hammer mill (SVS, Portable Multipurpose flour mill) and were mixed thoroughly in ribbon blender into smooth homogenous powder and then stored in airtight containers at room temperature (25 $-30^{\circ} \mathrm{C}$ ) until used. Ready-to-eat weaning mix of each formulated complementary foods was made by mixing flour in cold water at concentrations of $20 \%$ and then poured into boiling water $(200 \mathrm{ml})$ with the addition of 20 $\mathrm{g}$ of flour, stirred and allowed to remain heated for $5 \mathrm{~min}$ to form thick porridge, after which samples were taken for analyses.

\section{Nutritional composition}

The samples obtained from the different blends of complementary malted weaning mixes were analyzed for moisture, protein (N* 6.25), ash, crude fibre and crude fat (AOAC, 2012). Carbohydrate was determined by difference. Selected mineral contents (calcium and Iron) of malted weaning mixes were determined by using atomic absorption spectrophotometer (AAS) method (AOAC, 2000).

\section{Sensory evaluation}

Sensory evaluation of Ready-to-eat weaning mix of each formulated complementary foods was carried out on sensory attributes like taste, appearance, aroma, texture, colour and overall acceptability by a 6 semi-trained adult panelists which includes mothers with children age 6 to 48 months and 30 untrained children's age group 4 to 5 years. The acceptability of sensory assessments was conducted in 6 ANGANWADI centres at Tribal Areas of Adilabad. Balamrutham (wearing food weaning supplied through ANGANWADI centres to provide improved supplementary nutrition to children between 7 months to 3 years in Telangana state of India), energy rich complementary weaning food samples (A, B and C) were used in the evaluation. Samples were coded using random three-digit numbers and served with the order of presentation counter-balanced. Panelists were provided with a glass of water and, instructed to rinse and swallow water between samples. 
They were given written instructions and asked to evaluate the products for acceptability based on its flavour, texture, taste, color and overall acceptability using nine-point hedonic scale $(1=$ dislike extremely to $9=$ like extremely; Meilgaard et al., 1999 ). The range method of statistical analysis was applied for the test of the significance to find the preferences.

\section{Statistical analysis}

Results were expressed as mean \pm standard deviation. The difference between groups of each parameter was determined using the ttest and statistical significance was claimed at $\mathrm{P}<0.05$.

\section{Results and Discussion}

Germination and milling of germinated grains into malt is a simple process that is widely used for making complementary nutritious weaning foods from cereals and pulses. Table 2 showed result of nutritional composition of the formulated complementary weaning foods. Sample-C had significantly $(\mathrm{p}<0.05)$ lower mineral content $(2.4 \pm 0.1 \%)$ while comparable higher values of carbohydrates were recorded for Sample-A $(64.2 \pm 0.6 \%)$. Fat contents of Sample-B $(5.5 \pm 0.5 \%)$ and Sample-A $(5.4 \pm 0.1 \%)$ were significantly $(\mathrm{p}<$
$0.05)$ higher while Sample-A $(17.1 \pm 0.1 \%)$ significantly lower $(\mathrm{p}<0.05)$ in protein content. Mineral element concentrations showed that Sample-C which had significantly $(\mathrm{p}<0.05)$ higher calcium and Iron content then other samples. All the mixes were nutritional rich over the Balamrutham (wearing food weaning supplied through ANGANWADI centres to provide improved supplementary nutrition to children between 7 months to 3 years in Telangana state of India). The nutrient contents of Energy Rich Complementary Weanining Foods $(17.1 \pm 0.1 \%, 18.7 \pm 0.3$ and $18.5 \pm 0.6$ protein, and 367, 373 and 371, kcal/100 g for SampleA, Sample-B and Sample-C, respectively) fall in line with the guidelines of the Bureau of Indian Standards for protein-rich supplementary foods for children and mothers (Indian Standards Institution 1973). These nutritional compositions indicate that the energy rich complementary weaning foods have fairly balanced proteins and other nutrients. Similar findings were quoted by Sumathi et al., (2007) in scientific literature. Sensory quality of energy rich complementary weaning food sample-B compare to the regular supplemented food (Balamrutham) in ANGANWADI centers of the Telangana state was both liked moderately on the hedonic scale (Table 3).

Table.1 Different Energy Rich Complementary Weanining Mixes

\begin{tabular}{|c|l|c|c|c|}
\hline S.No & Ingredients in (\%) & Formulation- A & Formulation- B & Formulation- C \\
\hline 1 & Sorghum & 35 & 35 & 35 \\
\hline 2 & Wheat & 30 & 20 & 15 \\
\hline 3 & Ragi & 5 & 10 & 15 \\
\hline 4 & Soybean & 15 & 20 & 20 \\
\hline 5 & Green Gram & 15 & 15 & 15 \\
\hline & Total & 100 & 100 & 100 \\
\hline
\end{tabular}


Sorghum \& Ragi

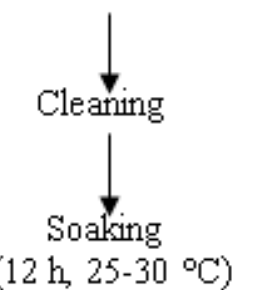

$\left(12 \mathrm{~h}, 25-30^{\circ} \mathrm{C}\right)$

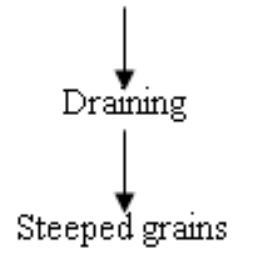

Germination (48 h)
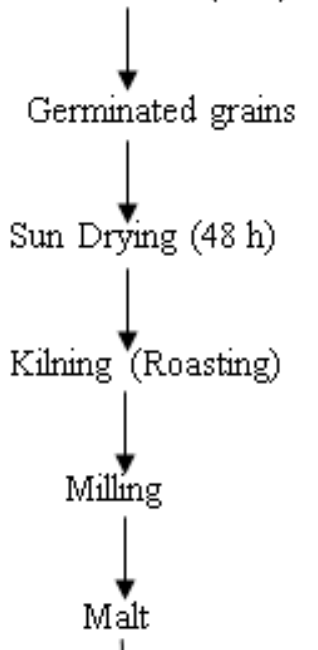

Soybean

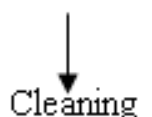

Soaking

$\left(12 \mathrm{~h}, 25-30^{\circ} \mathrm{C}\right)$

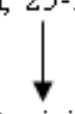

Draining
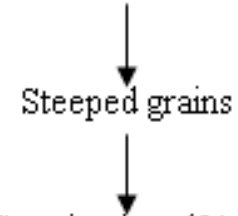

Germination $(54 \mathrm{~h})$

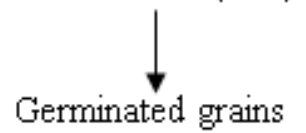

Germinated grains

Sun Drying (48 h)
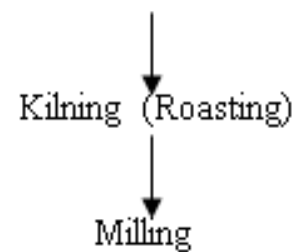

Milling

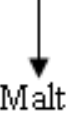

Green gram
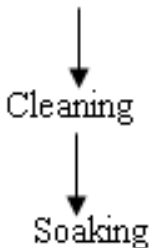

$\left(12 \mathrm{~h}, 25-30^{\circ} \mathrm{C}\right)$
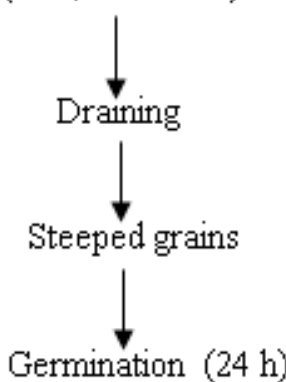

Germination (24 h)

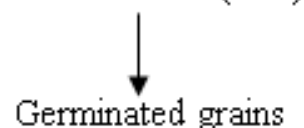

Grains
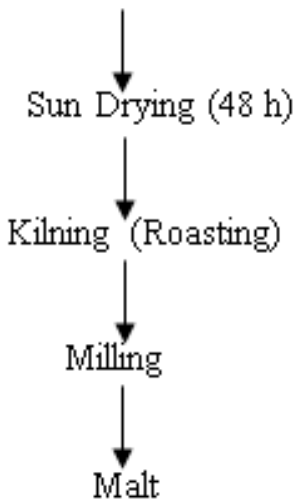

Wheat

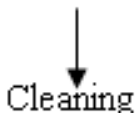

Soaking

$\left(12 \mathrm{~h}, 25-30^{\circ} \mathrm{C}\right)$
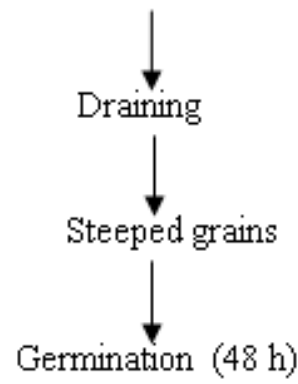

Germination $(48 \mathrm{~h})$

Germinated grains
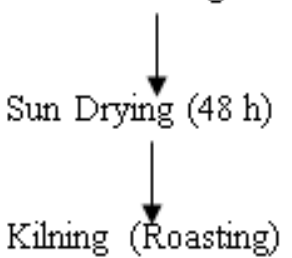

Blending

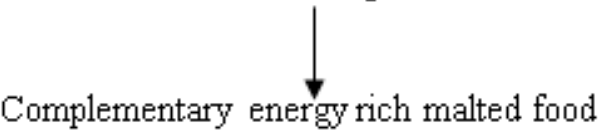

Figure1. Flow chart for preparation of energy rich complementary malted weaning food mixes 
Table.2 Nutrient composition of Energy Rich Complementary Weaning Foods for 100g*

\begin{tabular}{|c|c|c|c|c|}
\hline & Balamrutham & Formulation- A & Formulation- B & Formulation- $\mathrm{C}$ \\
\hline Calories (kcal) & 414 & $367 \pm 0.3$ & $373.0 \pm 0.5$ & $371 \pm 0.2$ \\
\hline Protein $(g)$ & 11.0 & $17.1 \pm 0.1$ & $18.7 \pm 0.3$ & $18.5 \pm 0.6$ \\
\hline Fat $(\mathrm{g})$ & & $4.7 \pm 0.2$ & $5.5 \pm 0.5$ & $5.4 \pm 0.1$ \\
\hline Carbohydrates (g) & & $64.2 \pm 0.6$ & $62.2 \pm 0.4$ & $62.2 \pm 0.3$ \\
\hline Dietary Fiber (g) & & $7.5 \pm 0.1$ & $7.2 \pm 0.2$ & $6.9 \pm 0.2$ \\
\hline Total Minerals & - & $2.2 \pm 0.2$ & $2.4 \pm 0.3$ & $2.4 \pm 0.1$ \\
\hline Calcium (mg) & 167 & $97.5 \pm 0.5$ & $125.0 \pm 0.6$ & $140.7 \pm 0.8$ \\
\hline Iron (mg) & 3.1 & $6.1 \pm 0.2$ & $6.7 \pm 0.5$ & $6.7 \pm 0.4$ \\
\hline
\end{tabular}

*All the values in Triplicate of analysis and presented as means \pm standard error

Table.3 Sensory evaluation of Energy Rich Complementary Weaning Foods**

\begin{tabular}{|l|l|l|l|l|l|l|}
\hline Samples & Appearance & Colour & Flavour & Texture & Taste & $\begin{array}{l}\text { Overall } \\
\text { acceptability }\end{array}$ \\
\hline control & $8.3 \pm 0.21$ & $8.6 \pm 0.23$ & $8.4 \pm 0.31$ & $8.8 \pm 0.32$ & $8.6 \pm 0.36$ & $8.9 \pm 0.28$ \\
\hline A & $8.1 \pm 0.13$ & $8.4 \pm 0.18$ & $8.1 \pm 0.23$ & $8.3 \pm 0.19$ & $8.1 \pm 0.27$ & $8.2 \pm 0.27$ \\
\hline B & $8.4 \pm 0.17$ & $8.7 \pm 0.19$ & $8.4 \pm 0.30$ & $8.9 \pm 0.11$ & $8.7 \pm 0.23$ & $8.6 \pm 0.13$ \\
\hline C & $8.2 \pm 0.26$ & $8.4 \pm 0.33$ & $8.2 \pm 0.17$ & $8.1 \pm 0.33$ & $8.4 \pm 0.33$ & $8.1 \pm 0.10$ \\
\hline \multicolumn{7}{|c}{$*$ All the values in Triplicate of analysis and presented as means \pm standard error } \\
\end{tabular}

The mean scores of sensory evaluation showed that all the energy rich complementary weaning food samples prepared from locally grown foods were within the acceptable range, while the energy rich complementary weaning food sample-B prepared from malted Sorghum: Wheat: Ragi: Soybean: Green Gram in the ratio of 35:20:10:20:15 had significantly better appearance $(8.4 \pm 0.17)$, color $(8.7 \pm 0.19)$, flavour (8.4 \pm 0.30$)$, texture $(8.9 \pm 0.11)$, taste $(8.7 \pm 0.23)$ and overall acceptability $(8.6 \pm 0.13)$.

Feeding infants with improved complementary malted foods prepared from locally available food crops as that formulated in this study for children in the state may cause improvement in their growth (Anigo et al., 2010).

The present study revealed that, energy rich complementary weaning food sample-B (Sorghum: Wheat: Ragi: Soybean: Green Gram in the ratios of 35:20:10:20:15) be used to produce nutritionally superior quality malted weaning food with the acceptable sensory properties. Further study also shows that the tribal families can prepare energy rich weaning mixes from their agriculture produce by simple malting and milling process. The millet proteins complement well with the soy 
as well as legume proteins, and the supplementary foods may be suitable for nutrition intervention programmes.

\section{References}

Association of Official Analytical Chemists (AOAC). (2012). Official Methods of Analysis of AOAC International. Gaithersburg: AOAC International.

Association of Official Analytical Chemists (AOAC) (2000). Association of Official Analytical Chemists Official journal 17th ed. Maryland: Gaithersburg, MD.

Adelekan, A. O. and Oyewole, O. B. (2010). Production of ogi from geminated sorghum supplemented with soybeans. A. J. of Bio. 9(42): 7114-7121.

Anigo K. M., D. A. Ameh1, S. I brahim and S. S. Danbauchi. (2010). Nutrient composition of complementary food gruels formulated from malted cereals, soybeans and groundnut for use in North-western Nigeria. A. J. Food Sci. 4(3): $65-72$.

Henkel J. (2000). Soy: health claims for soy protein, questions about other components. FDA Consumer Magazine 34(3).

Indian Standards Institution. (1973). Specification for protein-rich food supplements for infants and preschool children. No. 7021, New Delhi: ISI

Kannan SM, Thooyavathy RA, Kariyapa RT, Subramanian K, Vijayalakshmi K. (2013). Seed production techniques for cereals and millets. In: Vijayalakshmi
$\mathrm{K}$, editor. Seed node of the revitalizing rainfed agriculture network Centre for Indian knowledge systems (CIICS). 2013. p. 1-39. http:// www.ciks.org/downloads/seeds/5.\%20S eed $\% 20$ Production $\% 20$ Techniques $\%$ 20for\%20Cereals\%20and\%20Millets.pd f. Accessed 29 Dec 2017.

Kuan-I Chen, Mei-Hui Erh, Nan-Wei Su, Wen-Hsiung Liu, Cheng-Chun Chou and Kuan-Chen Cheng. (2012). Soyfoods and soybean products: from traditional use to modern applications. A. Micro. Bio. 96: 9-22.

Longvah T, Anathan R, Bhaskarachary K, and Venkaiah K. 2017. Indian Food Composition Tables (2017). Published by National Institute of Nutrition, ICMR, India.

Directorate of Economic and Statistics, government of Telangana http://ecostat.telangana.gov.in/PDF/PU BLICATIONS/Agricultural_at_glance_ 2015-16.pdf

Meilgaard, M., Civille, G.V. and Carr, B.T. 1999. Sensory Evaluation Techniques. Third edn. CRC Press, Boca Raton.

National Family Health Survey 2015-16 (NFHS-4).

http://rchiips.org/nfhs/FCTS/TG/TG_Fa ctSheet_532_Adilabad.pdf

Sumathi A, Ushakumari S. R. and Malleshi N.G. (2007). Physico-chemical characteristics, nutritional quality and shelf-life of pearl millet based extrusion cooked supplementary foods', Int. J. Food Sci. and Nutri. 58(5): 350 - 362.

\section{How to cite this article:}

Poshadri, A., Y. Praveen Kumar, G. Shiva Charan, M. Raghuveer, M. Sunil Kumar and Rama Devi, A. 2019. Energy Rich Composite Millet and Soybean based Malted Weaning Mix: A Complementary Food in Tribal Areas of Adilabad District, India. Int.J.Curr.Microbiol.App.Sci. 8(02): 2058-2064. doi: https://doi.org/10.20546/ijcmas.2019.802.238 